\title{
The Interplay between Career Decision Making Efficacy, Career Exposure and Career Choice of Undergraduates: Does Gender Matters?
}

\section{Nor Izan Abd. Karim and Roziah Mohd Rasdi}

To Link this Article: http://dx.doi.org/10.6007/IJARBSS/v11-i19/11722 DOI:10.6007/IJARBSS/v11-i19/11722

Received: 03 October 2021, Revised: 05 November 2021, Accepted: 26 November 2021

Published Online: 20 December 2021

In-Text Citation: (Karim \& Rasdi, 2021)

To Cite this Article: Karim, N. I. A., \& Rasdi, R. M. (2021). The Interplay between Career Decision Making Efficacy, Career Exposure and Career Choice of Undergraduates: Does Gender Matters? International Journal of Academic Research in Business and Social Sciences, 11(19), 131-146.

Copyright: (c) 2021 The Author(s)

Published by Human Resource Management Academic Research Society (www.hrmars.com)

This article is published under the Creative Commons Attribution (CC BY 4.0) license. Anyone may reproduce, distribute, translate and create derivative works of this article (for both commercial and non-commercial purposes), subject to full attribution to the original publication and authors. The full terms of this license may be seen at: http://creativecommons.org/licences/by/4.0/legalcode

Special Issue Title: Youth and Community Wellness, 2021, Pg. 131 - 146 


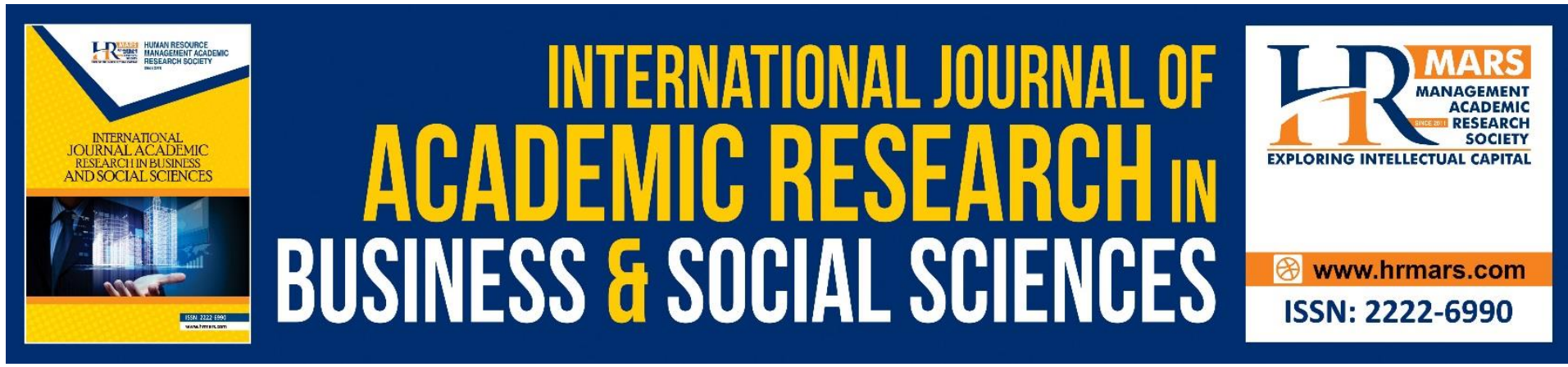

\title{
The Interplay between Career Decision Making Efficacy, Career Exposure and Career Choice of Undergraduates: Does Gender Matters?
}

\author{
Nor Izan Abd. Karim ${ }^{1}$ and Roziah Mohd Rasdi ${ }^{1,2}$ \\ ${ }^{1}$ Department of Professional Development and Continuing Education, Faculty of Educational \\ Studies, Universiti Putra Malaysia, 43400 Serdang, Selangor, Malaysia, ${ }^{2}$ Institute for Social \\ Science Studies, Universiti Putra Malaysia, 43400 Serdang, Selangor, Malaysia \\ Email: roziah_m@putra.upm.edu.my
}

\begin{abstract}
Lack of career exposure and rightful decision-making among university students has led to failure and inability to make a satisfying career choice. This lack of exposure emanates as a result poor supervision of programs which includes career education initiatives, workshops, seminars and internship programs which develops career self-efficacy among both of the genders. The aim of this study was to examine whether gender moderated the relationship between career decision-making self-efficacy, career exposure and career choice of Malaysian undergraduates. This study has employed a cross-sectional survey which involves a sample of 131 final-year students from eight faculties in a selected Malaysian public research university. The outcome of this study has demonstrated that there was a positive and moderate relationship between career decision-making self-efficacy and career choice $(r=0.452 ; p<0.001)$. The findings further indicate a positive and strong relationship between career exposure and career choice $(r=0.745 ; p<0.001)$. But gender did not moderate the relationship between career decision-making self-efficacy and career choice; neither did it moderate the relationship between career exposure and career choice. The implications of this study are that, both the colleges and faculties should offer a helping hand in encouraging student participation in activities such as organizing competition and designing programs that suit students' needs and challenges. It is recommended for universities in Malaysia to initiate a career counseling unit in all the universities and regenerate the existing ones, as that will facilitate lingering issues relating to career choice, career exposure and career decision making efficacy.
\end{abstract}

Keywords: Career Choice, Career Decision-Making Self-Efficacy, Career Exposure, Gender, Undergraduate Students

\section{Introduction}

Career choice among university students has brought about tremendous changes not only in the educational system but also in the global job market (Ganesan et al., 2018). These changes have impacted positively on the level of their exposure and also in terms of career choice. Undergraduate students are making a wise and good choice of career which will 
contribute to their future well-being and development. Studies have found that career choice is positively correlated with psychological, physical and socio-economic well-being. The influence of career choice will be felt both within the youthful age as well as adulthood (Robertson, 2014; Özbilgin et al., 2005; Bubić and Ivanišević, 2016). Brown (2004) asserts that the spirit of career choice must be inculcated to the students both at the tertiary level as well as in the secondary schools. According to Desimone et al. (2002), career choice is more about selection of vocation. A student irrespective of gender will have the opportunity to decide on what to do while in the course of his studies.

The fact that students have invested much time, energy, and money to earn a higher education degree shows that they really desire a dream job, but that does not mean that their dream will be fulfilled as soon as they finish their studies. Bandura (2001) argues that students are often confronted with the challenges of making good career choices. They need to select a satisfying career and plan how to equip themselves with the necessary skills or expertise (Feldman, 2003; Germeijs and DeBoeck, 2003). Graduates face difficulties in finding jobs that suits them in the labor markets except for those that are lucky enough to have a rightful choice of career. According to Wood (2004), students have very high expectations of their career and employment status. However, they face challenges such as a keenly competitive job market, unpredictable economic forces, and increasing unemployment (Ahmed et al., 2017; Olamide and Olawaiye, 2013). When making career choices, individuals are influenced not only by personality traits but also by various intrinsic and extrinsic factors (Ahmed et al., 2017). As such, when making decisions about career choice, students must be directed towards new emerging trends, future prospects and challenges as the right career choice will influence one's professional life and achievements in years to come.

Skills mismatch has become a lingering nightmare to both the graduates and industries. As employers bitterly complain about those that have graduated, but they cannot carry out the required skills and experiences expected of them. According to Sutherland and Ho (2017), employers nowadays not only look for graduates with outstanding technical skills and knowledge, but also those with outstanding personal attributes. Graduates who join the labor market must have previously possessed the requisite knowledge, skills, learning capabilities and positive attitudes, as well as the ability to adapt to evolving operations of the industry and changes in the labor market (Kamaliah et al., 2018).

Recent study conducted by Malaysian Ministry of Higher Education in (2018) on Graduate Tracking which involves about 702 universities with a total 341, 311 students. Accordingly, the highest number of graduates in 2018 were diploma holders ( 41.2 percent), followed by first degree holders (40.9 percent), certificate level (9.0 percent), masters' level (6.7 percent), PhD (1.5 percent) and other levels (0.6 percent). The findings showed that 67.8 percent of graduates were unemployed after their convocation although they had been actively looking for jobs. The study found that employers have developed the habit hiring holistic graduates who possessed not only the requisite skills and work experience but also soft skills. Based on the findings, graduates should not be too selective when hunting for their first jobs. What is more vital is to gain as much work experience by taking up any job offer, especially when one is graduate (Department of Statistics Malaysia, 2019).

Globally, unemployment has become a nightmare bedeviling many developing nations of the world, in which Malaysia is also inclusive. Unemployment has increased to 521,400 in the third quarter, as compared to 520,600 in the second quarter (Department of Statistics Malaysia, 2019). Graduates, especially those without working experience (mostly fresh 
graduates), despite their limitations, but they still struggle to make a career choice. Since majority of the students are young and inexperienced, they might end up making a wrong choice in their careers. This may be as a result of their lack of exposure or career self-efficacy.

\section{Literature Review \\ Career Choice}

Career choice is typically influenced by socio-cultural elements, personal and social qualities, culture values, structural factors such as women's challenges in certain profession (Swanson and Gore, 2000). It is important to ensure that undergraduates are able decide on what kind of career they want to achieve while in the university. They should explore a range of career choices through supervision and planning. According to Lent et al. (1994), career choice is guided by priorities which are influenced by self-efficacy, interest, and expectations. Undergraduates with high career self-efficacy tend to make career choices by themselves. A study by Nachmias and Walmsley (2015) showed that career decision-making self-efficacy (CDMSE) affected decisions on career choice. Hutaibat (2012), explains that difficulties in making career choice may be due to lack of career exposure. Hence, undergraduate students should receive career exposure from the university via different programs, including seminars, professional exhibition, and internships. Thus, adequate career exposure among university students will build self-confidence in making career choice.

Even with all the desirable attributes in place, undergraduates should have a clear direction of which career route to take after graduation. It is common for students, upon graduation, to seek employment in the field in which they major, i.e., according to their qualifications. However, been too particular about their first job, to be reluctant to work, or choosing not to work are some of reasons why many graduates remain unemployed (Hossain et al., 2018). Department of Statistics Malaysia (2019) conducted a study on the employability of Malaysian graduates, trends in the employment situation in Malaysia, and the qualities that top employers seek in Malaysian graduates. The study reported that most of the respondents (81 percent) believed that communication skills were a major problem for graduates and that 90 percent of graduates should acquire appropriate professional skills before graduation. Employers and policy-makers should, therefore, work together to conduct appropriate programs for undergraduate students to improve their employability, and help them make good career decisions. The wrong career choice can result in disappointment, causing one to be unproductive, and even exit the job market.

\section{Career Decision-Making Self-Efficacy and Career Choice}

In this study, self-efficacy refers to how people reflect on their ability to perform tasks that affect or change their lives. Self-efficacy can influence our insights, inspire us, and help us to make a decision. According to Choi and Kim (2013), self-efficacy has received the most research attention in relation to career preparation because it is central to successful career choices. Tsai et al (2017) reported that high career self-efficacy is related to career choice.

CDMSE indicates the individual's level of confidence as to whether he or she can successfully engage in tasks related to career choice (Austin, 2010; Gushue et al., 2006; Lent et al., 1994 Taylor and Betz, 1983). Individuals perform specific tasks or avoid them on the basis of their own judgment or competence (Bandura, 1986; Tang et al., 2008). Nachmias et al (2015) found that CDMSE influenced undergraduates' beliefs in making effective career choices. Chan et al (2018) also found that CDMSE was significantly and positively correlated with career choices of university students. 


\section{Career Exposure and Career Choice}

Career exposure refers to exposure to career-related information. Undergraduates obtain information about careers through industrial training or internship programs organized by the university as well as from companies' websites. According to $\mathrm{Ng}$ et al (2017), career exposure provides information about future careers available to students upon graduation. Career choice may seem discouraging and confusing to undergraduates who do not know the direction in which they are heading, especially when they are not exposed to job situations in the fields they might be interested in, and are thus not aware of the requirements by the employers Ghani et al (2008) reported on the importance of exposing students to opportunities in the job market, and the types of careers that might interest them. With greater exposure to career information, undergraduates can make better decisions about career choice.

It is also pertinent to examine how undergraduates' career choice is influenced. Personal, contextual, and behavioral variables are the three main variables involved in the career choice process (Flores et al., 2010, Rasdi et al., 2013). The factors that distinguished people from one another and they include factors like gender, race, age, field of education and personality (Bishop and Bieschke, 1998). In addition, Muhamad et al.'s (2016) study which focused on final year accounting students at a public university and who had undergone industrial training for six months, showed that throughout the industrial training, they were exposed to the realities of the working environment and principles of the organization. The participants have reported that exposure to industrial training helped them in making better decisions about their career choice. Additionally, Vocational scholars also stress the importance of career exposure, as it influences career studies, especially those that shape career goals as well as guide one's learning experiences (Blustein, 2001; Lent et al., 2000).

Curtis et al (2008) found out that the internship programs were the best way to offer undergraduates a true portrait of what specific jobs entails. Internship programs has given the undergraduates a better idea of career choice which will facilitate their chances of employment in the labor market. The findings of previous studies conducted by Odo's (2015) and Patton and McCrindle's (2001) have also showed that career exposure has help undergraduate students to be confident about making decisions about career choices. Hence, having access to career information is a crucial factor for successful career choice. Many studies have disclosed that career exposure by professional practitioner's influences career choice of students (Ghani et al., 2008; Sugahara and Boland, 2006; Hutaibat, 2012).

The above discussion on CDMSE and career exposure shows that these two variables have a strong influence on undergraduates' career choice. Thus, we hypothesize:

\section{H1. There is a positive relationship between CDMSE and career choice among undergraduates.}

H2. There is a positive relationship between career exposure and career choice among undergraduates.

\section{Gender as Moderator}

In this study we examine whether (i) gender moderates the relationship between CDMSE and career choice; and (ii) gender moderates the relationship between career exposure and career choice. Distinctions in social behavior between males and females are also seen to be interdependence discrepancies (Cross and Madson, 1997; Gabriel and Gardner 1999). Men are perceived as being more independent, while women are perceived as interdependent; 
and this uniqueness shape their cognitions, motivations and emotions (Cross and Madson, 1997).

According to Gottfredson (1981), gender is built into self-concept and influences career choice at an earlier age, because boys and girls have different values and interests. Career choice may change over time, especially when youths develop a clearer sense of self and take up different jobs (Gottfredson, 2005). Gottfredson's theory proposes that male and female are much more inclined to develop different career identities and all these subsequently influence them in making career choices upon completion of their studies.

Women are more likely than men to restrict their ultimate career choices because they believe that they lack the skills related to their career (Bandura, 1994; Chen et al., 1998). While Wolfe and Betz (1981) found out that gender moderated the relationship between CDMSE and career choice, whereas, as for Taylor and Popma (1990) gender did not moderate the relationship. Edwards and Quinter (2011) argued that most students do not consider gender as the most influential factor in career choice. In view of the above statement, it is thus hypothesizing as:

H3. Gender moderates the relationship between CDMSE and career choice among undergraduates.

H4. Gender moderates the relationship between career exposure and career choice among undergraduates.

\section{The Moderating Effect of Gender}

According to the International Labor Organization (2018), it is easy for men to get a job than women, as for women, getting a job nowadays has become a difficult task.

In 2017, the participation rate of women in the global labor force was approximately around 49 percent, as compared to 75 percent for men. Whereas the rate of unemployment among Malaysian men was 9.8 percent and 11.4 percent for women. Thus, the rate of unemployment for women was greater than of men respectively (International Labor Organization, 2019). This implies that women faced more difficulties in getting employment than their male counterpart. This may possibly be as a result of limited options for jobs or it may either be because of gender discrimination.

In the past, as a result of one reason or the other, gender roles were segregated and unequal in the workplace. As women in the workforces receive lower wage rates in comparation to men (Bronstein and Farnsworth, 1998), even though the gap between the two is currently not that wide. Studies have demonstrated that young men and women have different approaches to career choice. The level of thinking in men is more liberal and progressive whereas for the women, they prefer to think hierarchical (Kim, 2011). According to International Labor Organization (2019), the unemployment rate for women has always been relatively higher, while the rate for men is mostly lower. A study by Greenberger et al. (2000) dealing with the selection of different professions using gender have found out that certain traditional stereotypes do exist in both men and women, and they finally concluded that gender played a significant role in career choice. Thus, gender was incorporated as the moderator variable in this study.

Based on the discussions above, this study was aimed at examining the relationship between CDMSE and career exposure on career choice of among undergraduate students. Subsequently, the study will thus examine whether gender moderated these relationships. Additionally, the study used simple random sampling in selecting samples from eight faculties 
in a public university. The outcome of this study would be beneficial to undergraduate students, since this study will guide them while making a choice of career, it will also facilitate their chances of employment in the labor markets.

\section{Theorizing Career Choice among Undergraduate Students}

The social cognitive career theory (SCCT) developed by Lent et al. (1994) was used to provide theoretical support to individual's career choice. According to Lent et al. (1994), SCCT has to do with developing the process of an individual's career choice, vocational interests, and perseverance while pursuing his or her career path. As pointed out by Wang et al. (2007), the theory asserts that individual career choices and goals are driven by personal self-efficacy and career expectations. The theory has been regularly used in studies to examine career choices and career development (Ng et al., 2017; Rasdi et al., 2009).

The theory presents the three interlocking models, viz. (i) how career interest is developed; (ii) how career choice is made; and (iii) how career performance is attained (Lent et al., 1994). In this study, the second model was chosen, viz. how career choice is made, and its relationships with CDMSE and career exposure was examined. The theory posits that, those who have a high level of CDMSE are confident of successfully engaging and carrying out work related to career decision-making and career commitment.

As a result of the theory, undergraduate students gradually develop CDMSE by being exposed to various experiences related to their future career. The theory further posits that individual and environmental factors are correlated to students' career choices. Besides making career choices in line with their interests, students are also influenced by exposure to various career opportunities especially, job exposure is a significant factor in the development of students' career interests. Environmental factors such as family structure, parental and peer support also serve to shape their careers.

\section{Research Framework}

Research framework portraying the relationship between career exposure, career decision making efficacy on career choice and it is moderated by gender.

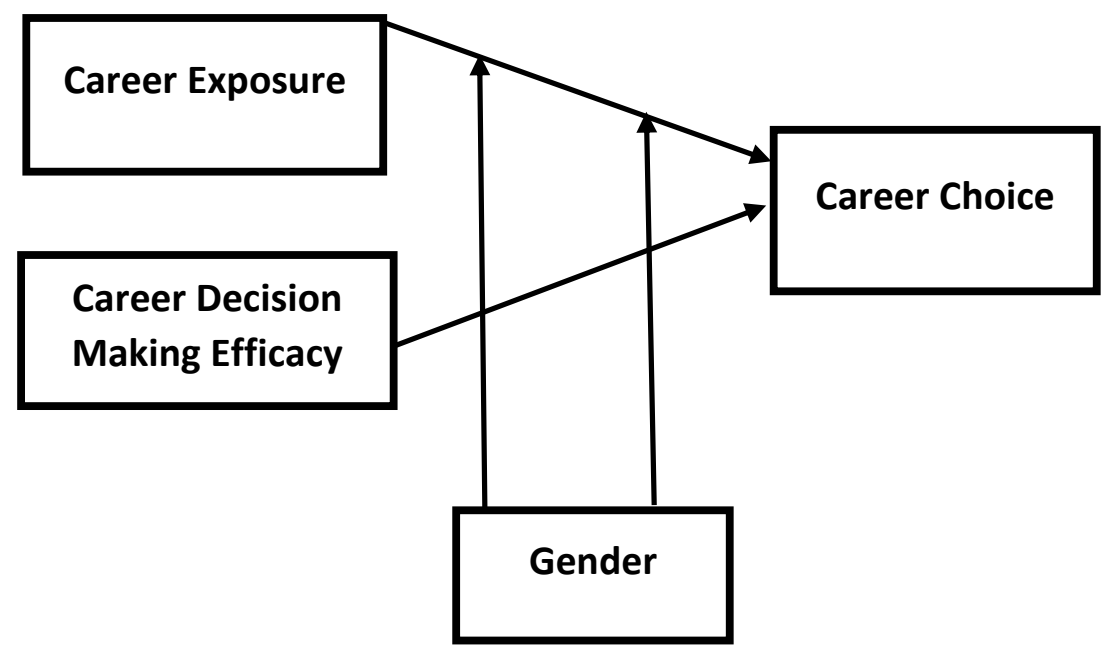

Figure 1: Showing Research Framework

\section{Methodology}

\section{Sample and Procedures}

Descriptive correlational design and cross-sectional study were used for the study. 
Final year undergraduate students from eight faculties served as the respondents of the study. The samples were selected randomly through the fish bowl technique. This study included final year undergraduate students because, they are about to graduate and finally apply the choice they made in their career for employment opportunities.

There were 131 students, with almost equal representation of gender: 62 were males (47.3 percent) and 69 females (52.7 percent). Their ages ranged from 20 ( 1 student) to 40 (1 student), with the average age being 23 years old.

\section{Instrumentation}

Survey questionnaire consisting of 38 items were adapted for use in this study. The online questionnaire was self-administered were also used in this study to elicits the responses of respondents. A pilot test was conducted on 30 undergraduate students prior to actual data collection to ensure reliability and validity of the instrument. The results showed that the internal consistencies for the scales ranges between $\alpha=0.80$ to $\alpha=0.86$, indicating high reliability for all the scales. The instrument was also checked and validated by a panel of experts in Human Resource Development Department and confirmed that all the items in the scales are reliable.

Career choice was measured using five items adopted and adapted from Yusoff et al. (2011). Responses from the items were rated using a four-point Likert-like scale, ranging from fully disagree (1) to fully agree (4). Sample items from this scale were: 'I clearly know my choice of sector" and "I clearly know my choice of career upon my graduation". In this section, internal consistency coefficient was 0.86 .

Career decision-making self-efficacy (CDMSE) was measured using items developed by Taylor and Betz (1983). The original version of CDMSE with 50 items was later modified to CDMSE short form (CDMSE-SF) with 25 items for efficient administration by Betz and Luzzo (1996). CDMSE items were rated on a five-point Likert-like scale, with responses ranging from no confidence at all (1) to complete confidence (5). A sample item: "Make a plan of your goals for the next five years". Betz and Luzzo (1996) reported that CDMSE-SF demonstrated stronger validity and reliability than the original scale, with the internal consistency of CDMSE ranging from 0.73 to 0.83 for the total 25 items; the reliability for the present study was based on CDMSE-SF was 0.864 scale.

Career exposure was measured using five items on a four-point Likert-like scale adopted and adapted from Hutaibat (2012), with responses ranging from fully disagree (1) to fully agree (4). An example of item from this scale: "I am given real case studies in university". In this section, the internal reliability coefficient was 0.80 .

\section{Result and Analysis \\ Findings}

The aim of this study was to examine the relationship between CDMSE and career choice, the relationship between career exposure and career choice among undergraduate students, as well as to determine whether gender moderated these relationships. before the data analysis, the data were tested for normality and linearity. The data were found to be normally distributed with skewness and kurtosis ranging between -1 and +1 , indicating that the normality was satisfied (George and Mallery, 2003). Thus, the data has met all the requirement for assumptions to carry out the parametric analyses such as Pearson Product Moment Correlation Coefficient and Multiple Linear Regression. 
Table 1 shows the Pearson correlation coefficients. Hypothesis 1 and hypothesis 2 postulate that there are significant relationships between CDMSE and career choice, and also between career exposure and career choice. The Pearson correlation coefficients showed that there was a positive and moderate relationship between CDMSE and career choice $(r=0.452 ; p<0.001)$. The results also indicated a positive and strong relationship between career exposure and career choice $(r=0.745 ; p<0.001)$. The higher the CDMSE and career exposure, the higher were the scores in respondents' career choices. This implies that increased confidence in making career decisions and high involvement in events and activities related to careers will increase the potential of undergraduates to have better insight and readiness for their career choice. Based on these findings, $\mathrm{H} 1$ and $\mathrm{H} 2$ were supported.

Table 1: Correlation, means and standard deviation of variables

\begin{tabular}{lccccc}
\hline \multicolumn{1}{c}{ Variables } & Mean & $\begin{array}{c}\text { Standard } \\
\text { Deviation }\end{array}$ & Y & $\mathbf{1}$ & $\mathbf{2}$ \\
\hline Y Career Choice & 3.90 & 0.38 & & & \\
X1 CDMSE & 3.30 & 0.52 & $.452^{* *}$ & $.747^{* *}$ & $.745^{* *}$ \\
X2 Career Exposure & 3.20 & 0.59 & $.747^{* *}$ &
\end{tabular}

Table 2 shows the model summary and coefficients for the model of undergraduates' career choice. A multiple regression model was calculated to investigate the factors contributing to undergraduate career choice. The adjusted R-squared value was used to avoid bias. The coefficient of determination (Adjusted $R^{2}=0.594$ ) showed that 59.4 percent of proportion of variance in career choice could be explained by the independent variables. The F-ratio showed that the independent variables significantly predicted the dependent variable, career choice $[F(2,128)=96.082, p<0.005]$. Thus, the model fitted the data. Results for the Multiple Linear Regression showed that the coefficient value for CDMSE $(\beta=0.353, p<0.05)$, career exposure $(\beta=0.753, p<0.05)$ were statistically significant, indicating that they were predictors of undergraduates' career choice.

Table 2: Estimates of coefficients for the model of career choice

\begin{tabular}{lrrr}
\hline Dimension & $\boldsymbol{\beta}$ & $\mathbf{t}$ & $\boldsymbol{p}$-value \\
\hline (constant) & -.624 & -1.760 & .081 \\
CDMSE & .353 & 3.807 & .000 \\
Career exposure & .753 & 11.263 & .000 \\
\hline
\end{tabular}

Note: Adjusted $R^{2}=0: 594 ; F=96.082 ; p=0.000$

\section{Testing for the Moderating Effect}

The moderation effects for gender on the relationship between CDMSE and career choice, and between career exposure and career choice were examined using the PROCESS macro (Hayes, 2013). Hypothesis 3 states that gender moderates the relationship between CDMSE and career choice, while hypothesis 4 states that gender moderates the relationship between career exposure and career choice.

In Table 3, the findings have demonstrated that the overall model was significant $(F$ $(3,127)=11.51, p<0.001)$. The interaction between CDMSE and gender was $(\beta=-.315 ; t=-1.27$; $p=0.2076)$. Further analysis revealed that the interaction of (CDMSE* gender) contributed 
about 0.29 percent of variance in career choice. This finding has indicated that the relationship between CDMSE and career choice was not moderated by gender, and thus, it has shown that, there were no difference in the relationships between CDMSE and career choice for both male and female undergraduate students.

Table 3: Moderating role of gender in relationship between CDMSE and career choice

\begin{tabular}{lrlrrrr}
\hline & coeff & \multicolumn{1}{l}{ se } & \multicolumn{1}{c}{ t } & \multicolumn{1}{l}{ p } & \multicolumn{1}{c}{ Lower } & \multicolumn{1}{c}{ Upper } \\
\hline Constant & 3.2025 & .0465 & 68.8049 & .0000 & 3.1104 & 3.2946 \\
Mean_SE & .6997 & .1244 & 5.6235 & .0000 & .4535 & .9458 \\
GenderNu & -.0169 & .0932 & -.1813 & .8564 & -.2014 & .1676 \\
Int_1 & -.3155 & .2491 & -1.2666 & .2076 & -.8085 & .174 \\
\hline
\end{tabular}

Overall Model: $F(3,127)=11.54, p<0.01, R^{2}=0.2142$

Table 4 depicts the results for the moderating effect of gender on the relationship between career exposure and career choice. It was revealed that the overall model showed a significant outcome $(F(3,127)=56.07, p<0.01)$. The interaction between career exposure and gender was $(\beta=-.233 ; t=-1.77 ; p=0.0784)$. Therefore, the relationship between career exposure and career choice was not moderated by gender, indicating that there was no difference between male and female respondents, with regard to the relationship between career exposure and career choice.

Table 4: Moderating roles of gender in relationship between career exposure and career choice

\begin{tabular}{lrlllrr}
\hline & coeff & se & t & p & \multicolumn{1}{l}{ Lower } & \multicolumn{1}{l}{ Upper } \\
\hline Constant & 3.2102 & .0340 & 94.4545 & .0000 & 3.1429 & 3.2774 \\
Mean_CE & .8300 & .0657 & 12.6426 & .0000 & .7001 & .9599 \\
GenderNu & -.0757 & .0681 & -1.1125 & .2680 & -.2104 & .0590 \\
Int_1 & -.2327 & .1311 & -1.7747 & .0784 & -.4922 & .0268 \\
\hline
\end{tabular}

Overall Model: $F(3,127)=5.07, p<0.01, R^{2}=0.5698$

Analysis of the data revealed that gender was not a significant moderator in the relationship between CDMSE and career choice, as well as in the relationship between career exposure and career choice. Hence, $\mathrm{H} 3$ and $\mathrm{H} 4$ were failed to support.

\section{Discussion}

In this study, we examined the relationship between CDMSE, career exposure and career choice of Malaysian undergraduates. We further examined whether gender moderated these relationships vis-à-vis career choice. The findings of this study indicated that there was significant influence between CDMSE and career exposure on career choice. However, we found that gender did not moderate these relationships.

Previous research findings on the relationships between CDMSE and career choice, and between career exposure and career choice found that these predictors variables were significantly correlated with career choice (Chan et al., 2018; Nachmias et al., 2015). The findings have shown that CDMSE had a positive relationship with career choice. This was probably due to the involvement of undergraduates in programs, activities, classroom presentations and so on. These has really exposed them to different careers. In addition, 
universities have also held different programs which involves the participation of the industries and community to enhance students' soft skills and confidence. Besides that, since the respondents were final year undergraduate students, majority of them have been actively involved in students' associations and have also held positions of responsibility.

The findings of this study would provide valuable insight on the factors that affect career choice of undergraduates. Besides that, research findings could also assist educational institutions and policymakers to design career guidance programs that expose students to sustainable careers upon graduation, and help them make good career decisions.

Hutaibat (2012); Ng et al (2017) were of the view that, there is a strong link between career exposure and career choice. Previously, career exposure has guide people on how view get new information (Kettlewell and Henry, 2009), enabling them to have wider world view in selecting a career for themselves. According to Kettlewell and Henry (2009), graduates make better career choices when they have exposure to knowledge of various professions. In fact, having career exposure prepares the individual for the job market and assist those who needs to make a career choice. In alignment with government policies to ensure students have made the rightful decisions about career choice, career exposure for undergraduates was carried out through seminars, programs, counseling sessions and also internship programs. Since the respondents are in their final year, they will convey them for an internship program during which they will be posted to different organizations, this will give them better insight of the working environment.

The results revealed that gender did not moderate the relationship between CDMSE and career choice as well as the relationship between career exposure and career choice. Taylor and Popma's (1990) and Chan's (2013) studies were in agreement with this finding. University environment has also become a source of information to students. The universities where this study was conducted was located in the metropolitan vicinity, and offered accessibility to many resources such as stable internet connection, seminars and programs. Both male and female students in the university were treated equally and exposure regardless of gender. Equal opportunities were also given to both male and female students when selecting which organizations, they will be having interest to conduct their internship programs. In addition, they were all given equal opportunity to conduct class presentations.

\section{Conclusion and Implications for Practice}

This study concludes that both individual and environmental factors are important for undergraduate students' career choice. However, gender is not a factor in this regard. Specifically, CDMSE and career exposure are important factors which assist undergraduates' students in making their career choice.

There are several practical implications based on the findings of the study. Since CDMSE and career exposure are essential components in the career choice of undergraduates, the authorities concerned should integrate these components into students' career planning and career development. Colleges and faculties should work hand-in-hand to offer more avenues to engage and encourage student participation, especially, organizing competitions, giving merit to students who participate and design programs that suit their needs and challenges. Outside parties such as those from the industry could contribute in terms of providing more opportunities for students which will be visible in the world of work. Additionally, they should also offer internships and specially designed programs to enable students to shoulder responsibilities as committee members in an event. Experiential learning will also improve 
students' soft skills as well as critical thinking ability, and help students make their career choice and career planning.

Students' ability to make career choices is also dependent on the environment in which they are exposed. Thus, universities should strive to enable undergraduates to acquire the requisite skills and knowledge relevant to the workforce, as well as providing opportunities for nurturing good values, potentials and competencies. Traditional and obsolete programs should be redesigned to trigger all learning domains and maximize the capability of students to engage and participate in the programs. Co-curricular activities designed by the universities should be revisited and revitalized so that they are aligned with contemporary demands in the workplace.

\section{Limitations and Future Research}

This study has few limitations. First, the findings of this study were based on data collected from a survey among randomly selected undergraduate students from a public research university. Thus, the findings of this study only represent the samples and population involved only and cannot be generalized to other samples such as from private universities or colleges.

Secondly, the study restricted the participants' responses to career choice factors listed in the questionnaire. Since it is a quantitative study, all factors were predetermined by the researcher based on literature review. This study thus examined only two factors, viz. CDMSE and career exposure, to represent the individual and environmental factors and their correlations with career choice. Additionally, the limitation of this study is that the information generated was based on an opinion survey. As such, data accuracy depends on respondents' honesty in answering the questions.

Future research should consider employing similar samples from other institutions in order to improve the degree of generalization of the present findings, especially, final year undergraduates in other tertiary institutions throughout the country should be selected. Further studies may perhaps employ a quantitative design that includes other potential predictors and develop a comprehensive career choice among undergraduates. A qualitative research design will also be another alternative to explore other potential factors associated with students' career choice.

\section{References}

Ahmed, K. A., Sharif, N., \& Ahmad, N. (2017a). Factors Influencing Students' Career Choices: Empirical Evidence from Business Students. Journal of Southeast Asian Research,2017. https://doi.org/10.5171/2017.718849

Austin, C. Y. (2010). Perceived factors that influence career decision self-efficacy and engineering related goal intentions of African American high school students. Career and Technical Education Research, 3(17), 119-135. https://doi.org/10.5328/cter35.310

Bandura, A. (2001). Social cognitive theory: An agentic perspective. Asian Journal of Social Psychology, 2, 21-41. https://doi.org/10.1111/1467-839X.00024

Bandura, A. (1994) Social Cognitive Theory and Exercise of Control over HIV Infection. In: DiClemente R.J., Peterson J.L. (eds) Preventing AIDS. Springer. https://doi.org/10.1007/978-1-4899-1193-3_3

Bandura, A. (1986). Social foundations of thought and action: A social cognitive theory. Prentice Hall.

Betz, N. E., \& Luzzo, D. A. (1996). Decision-making self-efficacy scale. Journal of Career Assessment, 4(4), 413-428. https://doi.org/10.1177/106907279600400405 
Bishop, R. M., \& Bieschke, K. J. (1998). Applying Social Cognitive Theory to Interest in Research among Counseling Psychology Doctoral Students: A Path Analysis. Journal of Counseling Psychology, 45(2), 182-188. https://doi.org/10.1037/0022-0167.45.2.182

Blustein, D. L. (2001). The Interface of Work and Relationships: Critical Knowledge for $21^{\text {st }}$ Century Psychology. The Counseling Psychologist, 29(2), 179-192. https://doi.org/10.1177/0011000001292001

Bronstein, P., \& Farnsworth, L. (1998). Gender differences in faculty experiences of interpersonal climate and processes for advancement. Research in Higher Education, 39(5), 557-585.

Brown, M. T. (2004). The Career Development Influence of Family Of Origin: Considerations Of Race/Ethnic Group Membership And Class. The Counseling Psychologist, 32(4), 587595. https://doi.org/10.1177/0011000004266007

Bubić, A., \& Ivanišević, K. (2016). The Role of Emotional Stability and Competence in Young Adolescents' Career Judgments. Journal of Career Development, 43(6), 498-511. https://doi.org/10.1177/0894845316633779

Chan, C. C., Chen, S. C., Lin, Y. W., Liao, T. Y., \& Lin, Y. E. (2018). Social Cognitive Perspective on Factors Influencing Taiwanese Sport Management Students' Career Intentions. Journal of Career Development, 45(3), 239-252. https://doi.org/10.1177/0894845316681643

Chen, C. C., Greene, P. G., \& Crick, A. (1998). Does Entrepreneurial Self-Efficacy Distinguish Entrepreneurs from Managers. Journal of Business Venturing, 13(4), 295-316. https://doi.org/10.1016/S0883-9026(97)00029-3

Choi, K., \& Kim, D. Y. (2013). A cross cultural study of antecedents on career preparation behavior: Learning motivation, academic achievement, and career decision selfefficacy. Journal of Hospitality, Leisure, Sport and Tourism Education, 13(1), 19-32. https://doi.org/10.1016/j.jhlste.2013.04.001

Cross, S. E., \& Madson, L. (1997). Models of the self: Self-construals and gender. Psychological Bulletin, 122(1), 5-37.

Curtis, A., Main, J., Main, P., \& Pitts, J. (2008). "Getting them early": The impact of early exposure to primary care on career choices of A-level students - A qualitative study. Education for Primary Care, 19(3), 274-284. https://doi.org/10.1080/14739879.2008.11493684

Department of Statistics Malaysia. (2019). Graduates Statistics 2019. Department of Statistics Malaysia. https://www.dosm.gov.my/

Desimone, L. M., Porter, A. C., Garet, M. S., Yoon, K. S., \& Birman, B. F. (2002). Effects of professional development on teachers' instruction: Results from a three-year longitudinal study. Educational Evaluation and Policy Analysis, 24(2), 81-112. https://doi.org/10.3102/01623737024002081

Edwards, K., \& Quinter. M. (2011). Factors influencing students career choices among secondary school students in Kisumu Municipality, Kenya. Journal of Emerging Trends in Educational Research and Policy Studies, 2(2), 81-87. https://hdl.handle.net/10520/EJC135714

Feldman, D. (2003). The antecedents and consequences of early career indecision among young adults. Humam Resource Management Review, 13(3), 499-531.

https://doi.org/10.1016/S1053-4822(03)00048-2 
Flores, L. Y., Robitschek, C., Celebi, E., Andersen, C., \& Hoang, U. (2010). Social cognitive influences on Mexican Americans' career choices across Holland's themes. Journal of Vocational Behavior, 76(2), 198-210. https://doi.org/10.1016/j.jvb.2009.11.002

Gabriel, S., \& Gardner, W. L. (1999). Are there 'his' and 'hers' types of interdependence? The implications of gender differences in collective versus relational interdependence for affect, behavior, and cognition. Journal of personality and social psychology, 77(3), 642655. https://doi.org/10.1037//0022-3514.77.3.642

Ganesan, J., Sin Kiat, K., \& Goh, C. (2018). Factors Influencing Career Choice Among Undergraduates. Science International, 30(6), 905-908.

George, D., \& Mallery, P. (2003). SPSS for Windows step by step: A simple guide and reference. 11.0 update (4th edition). Allyn \& Bacon.

Germeijs, V., \& De Boeck, P. (2003). Career indecision: Three factors from decision theory. Journal of Vocational Behavior, 62(1), 11-25. https://doi.org/10.1016/S00018791(02)00055-6

Ghani, E. K., Said, J., Nasir, N. M., \& Jusoff, K. (2008). The 21ST Century Accounting Career from the Perspective of the Malaysian University Students. Asian Social Science, 4,73.

Gottfredson, L. S. (1981). Circumscription and compromise: A developmental theory of occupational aspirations [Monograph]. Journal of Counseling Psychology, 28, 545-579. https://doi.org/10.1037/0022-0167.28.6.545

Gottfredson, L. S. (2005). Applying Gottfredson's Theory of Circumscription and Compromise in Career Guidance and Counseling.

Greenberger, E., Chen, C., Beam, M., Whang, S.-M., \& Dong, Q. (2000). The perceived social contexts of adolescents' misconduct: A comparative study of youths in three cultures. Journal of Research on Adolescence, 10(3), 365-388.

Gushue, G. V., \& Whitson, M. L. (2006). The relationship among support, ethnic identity, career decision self-efficacy, and outcome expectations in African American high school students: Applying social cognitive career theory. Journal of Career Development, 33,112-124. https://doi.org/10.1177/0894845306293416

Hayes, A. F. (2013). Methodology in the social sciences. Introduction to mediation, moderation, and conditional process analysis: A regression-based approach. Guilford Press.

Hossain, M. I., Yagamaran, K. S. A., Afrin, T., Limon, N., Nasiruzzaman, M., \& Karim, A. M. (2018). Factors Influencing Unemployment among Fresh Graduates: A Case Study in Klang Valley, Malaysia. International Journal of Academic Research in Business and Social Sciences, 8(9), 1494 - 1507. http://dx.doi.org/10.6007/IJARBSS/v8-i9/4859

Hutaibat, K. A. (2012). Interest in the management accounting profession: Accounting students' perceptions in Jordanian universities. Asian Social Science, 8(3). http://dx.doi.org/10.5539/ass.v8n3p303

International Labor Organization. (2018). The gender gap in employment: What's holding women back? -Info Stories. https://www.ilo.org/infostories/enGB/Stories/Employment/barriers-women\#intro

International Labor Organization. (2019). World Employment Social Outlook : Trends 2019. https://www.ilo.org/global/research/global-reports/weso/2019/WCMS_670554/lang-en/index.htm

Kamaliah, S., Roslan, S., Bakar, A. R., \& Ghiami, Z. (2018). The effect of supervised work experience on the acquisition of employability skills among Malaysian students. Higher Education, Skills and Work-Based Learning, 8(4), 354-364. 
https://doi.org/10.1108/HESWBL-05-2016-0028

Kettlewell, J. S., \& Henry, R. J. (2009). Increasing the competitive edge in math and science. Rowman and Littlefield Education.

Kim, M. (2011). The Relationship Between Thinking Style Differences and Career The Relationship Between Thinking Style Differences and Career Choices for High- Achieving Students Choices for High-Achieving Students. Roeper Review, 33(4), 252-262. https://doi.org/10.1080/02783193.2011.603113

Lent, R. W., Brown, S. D., \& Hackett, G. (1994). Toward a Unifying Social Cognitive Theory of Career and Academic Interest, Choice, and Performance. Journal of Vocational Behavior, 45(1), 79-122. https://doi.org/10.1006/jvbe.1994.1027

Lent, R. W., Brown, S. D., \& Hackett, G. (2000). Contextual Supports and Barriers to Career Choice: A Social Cognitive Analysis. Journal of Counseling Psychology, 47(1), 36-49. https://doi.org/10.1037/0022-0167.47.1.36

Muhamad, H., Salleh, M. M., Sufri, M., \& Nordin, M. (2016). Factors influencing career choice of accounting students in University Putra Malaysia: Qualitative pilot study. Journal of Advanced Research in Social and Behavioural Sciences Journal Homepage, 5, 25-34.

Nachmias, S., \& Walmsley, A. (2015). Making career decisions in a changing graduate labour market: A Hospitality perspective. Journal of Hospitality, Leisure, Sport and Tourism Education, 17, 50-58. https://doi.org/10.1016/j.jhlste.2015.09.001

Ng, Y. H., Lai, S. P., Su, Z. P., Yap, J. Y., Teoh, H. Q., \& Lee, H. (2017). Factors influencing accounting students' career paths. Journal of Management Development, 36(3), 319329. https://doi.org/10.1108/JMD-11-2015-0169

Odo, M. I. (2015). Sustaining Occupational Information for Career Choice and Development in Students of Technical Colleges in Enugu State, Nigeria. Journal of Technical Education and Training, $7(1)$.

Olamide, S. O., \& Olawaiye, S.O. (2013). 'The factors determining the choice of career among secondary school students. The International Journal of Engineering and Science, 2(6), 33-44

Özbilgin, M., Küskü, F., \& Erdoğmuş, N. (2005). Explaining influences on career "choice": The case of MBA students in comparative perspective. International Journal of Human Resource Management, 16(11), 2000-2028.

https://doi.org/10.1080/09585190500314797

Robertson, P. J. (2014). Health inequality and careers. British Journal of Guidance and Counselling, 42(3), 338-351. https://doi.org/10.1080/03069885.2014.900660

Rasdi, M. R., Ismail, M., Uli, J., \& Noah, M. S. (2009). Towards developing a theoretical framework for measuring public sector managers' career success. Journal of European Industrial Training. 33(3), 232-254. https://doi.org/10.1108/03090590910950596

Rasdi, M. R., Garavan, T. N., \& Ismail, M. (2013). Networking Behaviours and Managers' Career Success in the Malaysian public service: The Moderating Effect of Gender. Personnel Review. 42(6), 684-703. https://doi.org/10.1108/PR-07-2010-0117

Sugahara, S., \& Boland, G. (2006). Perceptions of the certified public accountants by accounting and non-accounting tertiary students in Japan. Asian Review of Accounting, 14(1-2), 149-167. https://doi.org/10.1108/13217340610729518

Sutherland, K., \& Ho, S. (2017). Undergraduate perceptions of social media proficiency and graduate employability a pilot study. Higher Education, Skills and Work-Based Learning, 7(3), 261-274. 
Swanson, J. L., \& Gore, P. A. (2000). Advances in Vocational Psychology Theory and Research. In Handbook of counseling psychology (pp. 233-269). Wiley.

Tang, M., Pan, W., \& Newmeyer, M. D. (2008). Factors influencing high school students' career aspirations. Professional School Counseling, 11, 285-295. https://doi.org/10.1177/2156759X0801100502

Taylor, K. M., \& Betz, N. E. (1983). Applications of self-efficacy theory to the understanding and treatment of career indecision. Journal of Vocational Behavior, 22(1), 63-81. https://doi.org/10.1016/0001-8791(83)90006-4

Taylor, K. M., \& Popma, J. (1990). Construct validity of the Career Decision-Making SelfEfficacy scale and the relationship of CDMSE to vocational indecision. Journal of Vocational Behavior, 37, 17-31.

Tsai, C. T. (Simon), Hsu, H., and Yang, C. C. (2017). Career decision self-efficacy plays a crucial role in hospitality undergraduates' internship efficacy and career preparation. Journal of Hospitality, Leisure, Sport and Tourism Education, 21, 61-68. https://doi.org/10.1016/j.jhlste.2017.08.002

Wang, C., Lo, Y. Y., Xu, Y., Wang, Y., \& Porfeli, E. (2007), “Constructing the search for a job in academia from the perspectives of self-regulated learning strategies and social cognitive career theory", Journal of Vocational Behavior, 70(3), 574-589. https://doi.org/10.1016/j.jvb.2007.02.002

Wolfe, L. K., \& Betz, N. E. (1981). Traditionality of choice and sex role identification as moderators of the congruence of occupational choice in college women. Journal of Vocational Behavior, 19, 61-77.

Wood, F. B. (2004). Preventing postparchment depression: A model of career counseling for college seniors. Journal of Employment Counseling, 41(2), 71-79.

https://doi.org/10.1002/j.2161-1920.2004.tb00880 